\title{
Study on sickle cell disease haplotypes reveals the African origin of Amapás population
}

\author{
Estudo dos haplótipos da doença falciforme revela a origem \\ afrodescendente da população amapaense
}

Natália de Morais Castelo ${ }^{1}$; Rafael Espíndola do Nascimento²; Artemis Socorro do Nascimento Rodrigues ${ }^{3}$

\begin{abstract}
Introduction: Sickle cell disease (SCD) is a hereditary, hematologic, multifactorial disease, with high prevalence worldwide; its cause is a mutation in the sixth codon of the beta globin gene ( $\beta$ s). Objective: To identify the haplotypes present in people with SCD in Amapá, and relate them to African descent. Methods: We analyzed, by molecular techniques, 46 blood samples from people with SCD in Macapá, the capital of Amapá, with the purpose of obtaining information about haplotype frequency distribution, which helps understand the ethnic background of Amapás population. Results: Our study revealed that the most frequent haplotype is Bantu (61.2\%), followed by Benin (26.6\%) and Senegal (12.2\%). Results showed statistical differences from studies conducted in other regions. A high frequency of the Senegal haplotype stands out, in comparison with some Brazilian studies. Conclusion: Amapás results exhibit unique characteristics when compared to haplotypes in other regions, with high frequency of Senegal and Benin haplotypes, absence of atypical, Cameroon and Saudi, confirming that Brazil shows ethnic background diversity, as well as different haplotype frequencies.
\end{abstract}

Key words: HbS haplotypes; afro-descendants; Amapá.

\section{INTRODUCTION}

Sickle cell disease (SCD) is the most common genetic disease in the world, with high prevalence in African descent populations. It is characterized by changes in hemoglobin, the red blood pigment responsible for carrying oxygen to the body tissues. Without flexibility to pass through small capillaries, red blood cells accumulate and obstruct blood circulation, decreasing the oxygen supply to tissues and organs of the body systems ${ }^{(1,3,22)}$.

According to the literature, the mutation of genes that causes SCD is associated with the body's response to an aggression against erythrocytes by Plasmodium falciparum, the causative agent of malaria. This hypothesis is supported by the argument that the prevalence of malaria in Africa has been high for millennia. And also by the fact that people with sickle cell trait acquired malaria immunity ${ }^{(2,3,15)}$.
Hemoglobin S or sickle hemoglobin (HbS) haplotypes are named according to their original regions. In Africa, the HbS gene is associated with haplotypes representing four independent mutations; in the Arabian Peninsula or Central India, mutation has occurred at least once. Benin, Senegal and Bantu haplotypes respectively include: Nigeria, Morocco, Benin, countries right of Benin, the Mediterranean, North and Central West Africa; regions of Senegal, Atlantic West Africa, up the Niger River; Central and South African countries. Cameroon haplotypes come from the central area of Cameroon. Saudi, the fifth haplotype, is found in the eastern province of Saudi Arabia and in Central India ${ }^{(1,3,7,13)}$.

The determination of HbS haplotypes is important not only to the monitoring and the prognosis of individuals who present the most severe form of the disease (sickle cell anemia [HbSS]). It is also a tool for anthropological studies intended to trace the origins of populations that have contributed a lot to shape the ethnic, economic, cultural and social development of the Americas, especially of Brazil ${ }^{(1,13,17)}$.

First submission on $04 / 10 / 13$; last submission on $22 / 10 / 13$; accepted for publication on $01 / 11 / 13$; published on 20/02/14

1. Master's degree in Health Sciences from Universidade Federal do Amapá (Unifap).

2. Biomedical of Centro de Hematologia e Hemoterapia do Amapá (HEMOAP).

3. Doctorate in Internal Medicine from Universidade Estadual de Campinas (Unicamp); full-time associate professor II at Unifap. 
This study aimed at providing important information on the molecular characterization of patients with SCD in Macapá, helping to reveal the origins of Amapá's population ethnic background.

\section{METHOD}

In this study we analyzed 46 samples from people with HbSS, male and female, without family ties (not consanguineous), who had not received a blood transfusion in the three months before collection, aged between 2 and 50 years, who were treated at Amapá’s Hematology Institute (HEMOAP).

The research project was approved by the Ethics Committee of Universidade Federal do Amapá (UNIFAP), according to the protocol FR - 476933/2012 - CEP. Participants and/or participants' guardians were informed about the study objectives and procedures, dispelling any existing doubt. All of them signed the consent form.

A screening for hemoglobinopathies was performed in the laboratory, by alkaline electrophoresis $(\mathrm{pH}$ 8.6), acid electrophoresis ( $\mathrm{pH}$ 6.2), and high pressure liquid chromatography $\left(\right.$ HPLC) ${ }^{(5)}$. Afterwards, we proceeded to deoxyribonucleic acid (DNA) extraction with phenol/chloroform, confirming HbSS presence through the polymerase chain reaction (PCR) technique followed by DdeI endonuclease cleavage ${ }^{(5)}$.

To identify the haplotypes, DNA was amplified and cleaved with restriction enzymes (PCR-restriction fragment length polymorphism [RFLP]), according to the method by Sutton et al. (1989): XmnI 5' $\gamma \mathrm{G}$; Hind III $\gamma \mathrm{G}, \gamma \mathrm{A}$ HindIII, HincII $\psi \beta ; 3^{\prime} \psi \beta$ Hinc II, Hinf I 5's, the specific polymorphic sites ${ }^{(5)}$.

\section{RESULTS}

Among the 46 analyzed samples, three haplotype kinds were identified. The most frequent was Bantu (61.2\%), followed by Benin (26.6\%), and Senegal (12.2\%), with absence of Cameroon, Saudi, atypical or indeterminate haplotypes being observed. Results also indicated presence of the Senegal haplotype, although it is uncommon in our population.

\section{DISCUSSION}

Haplotypes are considered anthropological genetic markers. In countries of the American continent, haplotype identification allows deciphering the ethnic origins and the history of the very mixed populations ${ }^{(3,13,14)}$.
Their identification is also important to explain the clinical diversity of sickle cell anemia, the worst form of SCD. The Senegal haplotype is associated with $\mathrm{HbF1}$ higher levels, corresponding to the milder disease form; Bantu, the most common haplotype in our population, is related to low $\mathrm{HbF}$ levels, corresponding to the most severe form. Thus, one may observe that the sickle cell anemia severity and clinical course are heterogeneous and modulated by several factors, among them, HbS haplotypes ${ }^{(11,23,24,26)}$.

According to studies conducted on HbS haplotypes, we observed the proportion of patients with different haplotypes in different regions of the Americas, particularly in Brazil, which has a high and important miscegenation. In North America and the Caribbean, the Benin haplotype predominates, followed by Senegal and Bantu, while in Brazil, although there is some regional diversity, in general, Bantu prevails, followed by Benin. Senegal has a low frequency, $y^{(3,13,14,10)}$.

The haplotype determination of most Brazilian studies (Bantu $\rightarrow$ Benin $\rightarrow$ Senegal) corroborates the data found in the Amapá state, which, from the 46 analyzed samples (HbSS), three haplotypes were determined: Bantu (61.2\%), Benin (26.6\%) and Senegal (12.2\%). This result is consistent with historical records indicating that about $90 \%$ of the slaves sent to Northern Brazil were from Angola, Congo and Mozambique, where the Bantu haplotype predominates ${ }^{(19,25,26)}$. However, it must be emphasized that in this study a high frequency of the Senegal haplotype (12.2\%) was found, when compared with other Brazilian studies.

The Senegal haplotype frequency in Amapá is confirmed by historical data, indicating that nearly $10 \%$ of Western Atlantic African slaves (precisely from Senegambia, Guinea-Bissau and Cape Verde, where the Senegal haplotype is prevalent) were destined to Northern Brazil. This finding is similar to studies conducted in Pará (66\% Bantu, 21.8\% Benin, 10.9\% Senegal, and 1.3\% Cameroon; 60\% Bantu, 27\% Benin, 12\% Senegal, and 1\% Cameroon), as would be expected, since Amapá once belonged to Pará, meaning that both populations share ethnic origins ${ }^{(9,10,12)}$.

At a semi-detached community in Amapá (Curiaú), located inside the capital, the results of some studies were uncommon compared with those of other Brazilian regions and similar to current Amapá data, as 50\% Bantu, 33\% Senegal and 17\% Benin were found. This is attributable especially to the founder effect and to the French Guiana's population, which used to migrate to Northern Brazil, since most of the slaves brought to that country were from Senegambia and Guinea, in West Africa. Thus, these results indicate that the contribution of West African people to the Amazonian populations was heterogeneous ${ }^{(17,20,21)}$.

In Colombia, a South American country, a high frequency of the Senegal haplotype (36.4\% Bantu, 30.3\% Senegal, 21.2\% 
Benin, and 12.1\% Cameroon) is observed, like in Northern Brazil. However, there is low frequency of the Benin haplotype. Meanwhile, the Southeast Region of Brazil (Rio de Janeiro), which received slaves mainly from Central Africa, corresponds to the Brazilian standard, with predominance of Bantu, followed by Benin, and low or no Senegal frequency ${ }^{(6,7,17)}$.

The Northeast Region was heavily stocked with slaves from Western Central Africa, where the Benin haplotype predominates $^{(12,21)}$. So, differently from the Brazilian standard distribution and frequency of Amapá haplotypes, there is data found in the Northeast (Ceará, Brazil) with high Benin haplotype frequency, resembling the standard Venezuelan haplotype (Benin is the most common: $47.9 \%$, Bantu: $40.6 \%$, Senegal: $3.1 \%$, Saudi: 2.1\%, and atypical: $6.3 \%)^{(7,16,18-20)}$.

This distribution reflects very well the different proportions of African slaves brought to the Americas during the slave trade, especially to Brazil, which has a different characteristic from that observed in other areas where HbSS prevails. As a result, this disease shows particularities in the Brazilian population ${ }^{(14,16,23)}$.

There is considerable Benin haplotype frequency (26.5\%) in Amapá's data, diverging from historical records that suggest a lower Benin frequency (about 2.9\%), so when faced with the
Brazilian standard frequency, both Pará (Benin: 30\%, 27\%, 21.8\%) and Amapá have high Benin frequency. These results are probably due to the slave trade and the domestic internal migration from other regions (Bahia, Pernambuco, Maranhão and Rio de Janeiro) to the north, since there are no historical records of slave trade directly from West Central Africa to the North Region ${ }^{(4,10,12,26)}$.

It is noteworthy that in the present study Cameroon and Saudi haplotypes were not found, similarly to what happened in the study by Adorno et al ${ }^{(2)}$ conducted in Bahia. However, in this study atypical haplotypes were determined, differently from Amapás data (without atypicals).

Thus, Amapá's results exhibit unique characteristics when related to haplotypes in other regions, with high frequency of Senegal and Benin; and absence of atypical, Cameroon and Saudi, which confirms Brazil's diversity of ethnic backgrounds, as well as different haplotype frequencies.

\section{ACKNOWLEDGEMENTS}

We thank Dr. Claudia Bonini, for her technical support; all the people of the Blood Center of Amapá; and the patients with sickle cell disease who agreed to participate.

\section{RESUMO}

Introdução: A doença falciforme éuma doença hereditária, hematológica, de caráter multifatorial, com alta prevalência mundial; sua causa é a mutação no sexto códon do gene da globina beta (ßs). Objetivo: Identificar os haplótipos presentes em indivíduos com doença falciforme no Amapá e relacioná-los com a origem afrodescendente. Método: Foram analisadas por meio de técnicas moleculares 46 amostras de sangue de indivíduos com doença falciforme de Macapá, capital do Amapá, com a finalidade de fornecer informações sobre a distribuição das frequências dos haplótipos, contribuindo para o entendimento da formação étnica da população amapaense. Resultados: Nosso estudo revelou que o mais frequente éo haplótipo Bantu (61,2\%), seguido de Benin (26,6\%) e Senegal (12,2\%). Nossos resultados apresentaram diferenças estatísticas em relação a estudos realizados em outras regiões, destacando-se que o presente estudo mostra uma frequência elevada do haplótipo Senegal quando comparado com alguns estudos brasileiros. Conclusão: Os resultados amapaenses apresentam características únicas quando relacionados com os haplótipos de outras regiões, com alta frequência de Senegal e Benin, ausência de atípicos, Camarões e Saudi, confirmando que o Brasil apresenta diversidade de origens étnicas, bem como diferentes frequências de haplótipos.

Unitermos: haplótipos Hbs; afrodescendentes; Amapá.

\section{REFERENCES}

1. ADORNO, E. V. et al. Clinical and molecular characteristics of sickle cell anemia in the northeast of Brazil. Genet Mol Biol, vol. 31, n. 3, p. 621-5, 2008.
2. ADORNO, E. V. et al. ßS-Haplotypes in sickle cell anemia patients from Salvador, Bahia, Northeastern Brazil. Braz J Med Biol Res, v. 36, n. 10, p. 1.283-8, 2003.

3. AURICCHIO, M. T. B. M. Frequency and origins of hemoglobin S mutation in African-derived Brazilian populations. Hum Biol, v. 79, n. 6 , p. 667-77, 2007. 
4. AGUIAR, G. F. S. et al. Genetical-demographic data from two Amazonian populations composed of descendants of African slaves: Pacoval and Curiau. Gen Mol Biol, v. 22, n. 2, p. 162-7, 1999.

5. BONINI-DOMINGOS, C. R. Metodologias laboratoriais para o diagnóstico de hemoglobinopatias e talassemias. São José do Rio Preto, SP: HN Editora, 2006.

6. BLANCO, Z. et al. Beta-globin gene cluster haplotypes in Venezuelan sickle cell patients from the State of Aragua. Genet Mol Biol, v. 25, n. 1, p. 21-34, 2002.

7 CABRAL, C. H. K. et al. Determination of $\beta$ s haplotypes in patients with sickle-cell anemia in the state of Rio Grande do Norte, Brazil. Genet Mol Biol, v. 34, n. 3, p. 421-4, 2011.

8. CASTILHOS, J. K.Análise de haplótipos $\beta$ S em pacientes com anemia falciforme de Porto Alegre - RS. Nova Hamburgo, 2008. Trabalho de Conclusão de Curso II, Centro Universitário Feevale, Instituto de Ciências da Saúde, 2008.

9. CARDOSO, G. L; GUERREIRO, J. F. African gene flow to North Brazil as revealed by HBB*S gene haplotype analysis. Am J Hum Biol, v. 18, n. 1, p. $93-8,2006$.

10. CARDOSO, G. L; GUERREIR0, J. F. Molecular characterization of sickle cell anemia in the Northern Brazilian state of Pará. Am J Hum Biol, v. 22, n. 5, p. 573-577, 2010.

11. CIPOLOTTI, R. et al. Diversidade clínica e laboratorial no haplótipo bantu da anemia falciforme. Rev Bras Hematol Hemoter, v. 28, n. 1, p. 40-4, 2006.

12. COSTA, P; SARNEY, J.Amapá: a terra onde o Brasil começa. Brasília: Senado Federal, p. 240, 1998.

13. DESAI, D. V; DHANANI, H. Sickle cell disease: history and origin. The Internet Journal of Hematology, v. 1, n. 2, 2004.

14. DUNDA-BELKHODJA, 0. et al. Evidence for the multicentric origin of the sickle cell hemoglobin gene in Africa. Proc Natl Acad Sci USA, v. 81, n. 6, p. $1771-3,1984$.
15. DIAS, E. T.A. L. A saúde da criança com doença falciforme: desempenho escolar e cognitivo. R Educ Publ, v. 22, n. 49/2, p. 575-94, 2013.

16. FARIAS, D. A. B. et al. Análise dos haplótipos do gene da ßS-globina no Ceará.J Bras Patol Med Lab, v. 41, n. 5, p. 315-21, 2005.

17. FLEURY, M. K. Haplótipos do cluster da globina beta em pacientes com anemia falciforme no Rio de Janeiro: aspectos clínicos e laboratoriais Rev Bras Anal Clin, v. 39, n. 2, p. 89-93, 2007.

18. GUERREIRO, J. F. et al. Origin of the hemoglobin $\mathrm{S}$ gene in a northern Brazilian population: the combined effects of slave trade and internal migrations. Genet Mol Biol, v. 21, n. 4, p. 427-30, 1998.

19. GUERREIRO, J. F. $\beta$-globin haplotypes analysis in Afro-Brazilians from the Amazon region: evidence for a significant gene flow from Atlantic West Africa. Ann Hum Biol, v. 26, n. 4, p. 365-73, 1999.

20. MOAFI, A. R. et al. $\beta^{\mathrm{s}}$ gene in Central Iran is in linkage disequilibrium with the Indian-Arab haplotype. Am J Hematol, v. 65, n. 3, p.192-5, 2000

21. NETO, G. C. G; PITOMBEIRA, M. S. Aspectos moleculares da anemia falciforme. J Bras Patol Med Lab, v. 39, n. 1, p. 51-6, 2003.

22. PAIVA, S. D. Aluno falciforme: o paradoxo da inclusão escolar conhecer para melhor atender. Belém, 2007. Trabalho de Conclusão de Curso - Universidade Estadual Vale do Acaraú, 2007.

23. PINTO, A. C. S; ZAGO, M. A. Fisiopatologia das doenças falciformes: da mutação genética à insuficiência de múltiplos órgãos. Rev Bras Hematol Hemoter, v. 29, n. 3, p. 207-14, 2007.

24. ROMERO, W. E. R; RENAULD, G. F. S; VILLALOBOS, M. A. C. Haplotipos de la hemoglobina S: importancia epidemiológica, antropológica y clínica. Rev Panam Salud Publica, v. 3, n. 1, p. 1-6, 1998.

25. STEINBERG, M. H. Genetic etiologies for phenotypic diversity in sickle cell anemia. The Scientific World Journal, v. 18, n. 9, p. 46-67, 2009.

26 TAVARES, M. G. C. A Amazônia brasileira: formação histórico-territorial e perspectivas para o século XXI. GEOUSP - Espaço e Tempo, n. 29, p. 107-21, 2011.

\section{MAILING ADDRESS}

